Anuario de Estudios Medievales

43/2, julio-diciembre de 2013, pp. 543-576

ISSN 0066-5061

doi:10.3989/aem.2013.43.2.02

\title{
ESCÁNDALOS, RUYDOS, INJURIAS E COCHILLADAS: PRÁCTICAS DE VIOLENCIA EN EL CLERO CATEDRALICIO BURGALÉS DURANTE EL SIGLO XV ${ }^{1}$
}

\author{
ESCÁNDALOS, RUYDOS, INJURIAS E COCHILLADAS: \\ PRACTICES OF VIOLENCE AMONG THE CATHEDRAL CLERGY \\ OF BURGOS IN THE FIFTEENTH CENTURY
}

\author{
JORGE DÍAZ IBÁÑEZ \\ Universidad Complutense de Madrid
}

\begin{abstract}
Resumen: El objetivo de este trabajo, basado fundamentalmente en fuentes manuscritas e inéditas procedentes del Archivo Catedralicio de Burgos, es el estudio y análisis de la violencia, tanto física como verbal, en el seno del clero catedralicio burgalés, poniendo de relieve la dimensión tanto individual como colectiva de los enfrentamientos y su variada casuística. El cabildo catedralicio burgalés ejerció su jurisdicción imponiendo castigos a los culpables, fomentando fórmulas de reconciliación y tratando de frenar, a menudo sin éxito, unos enfrentamientos entre clérigos que aumentaron durante las últimas décadas del siglo XV, y que guardan un estrecho paralelismo y relación con los conflictos que en la misma época se produjeron entre diferentes familias y linajes de la oligarquía urbana burgalesa.
\end{abstract}

Palabras clave: Corona de Castilla; Burgos; cabildo catedralicio; clero; violencia; siglo XV.

\begin{abstract}
The aim of this work, based mainly on manuscripts and unpublished documents from Burgos Cathedral Archive, is the study and analysis of violence, physical and verbal, among the cathedral clergy of Burgos, emphasizing the individual and collective scale of the conflicts and the variety of their causes. The cathedral chapter of Burgos exercised its jurisdiction by punishing the culprits, favouring reconciliation processes and trying to stop, often unsuccessfully, the conflicts between clergymen that increased during the last decades of the fifteenth century, and that have a close connection with the conflicts which took place between different families and lineages of the urban oligarchy of Burgos during the same period.
\end{abstract}

Keywords: Crown of Castile; Burgos; cathedral chapter; clergy; violence; fifteenth century.

1 Este trabajo ha sido realizado en el marco del Proyecto de Investigación financiado por el Ministerio de Ciencia e Innovación núm. HAR2010-16762, titulado: Prácticas de consenso y de pacto e instrumentos de representación en la cultura política castellana (siglos XIII al XV). Abreviaturas utilizadas: $\mathrm{ACB}=$ Archivo Catedralicio de Burgos; AGS = Archivo General de Simancas. 


\section{SUMARIO}

1. Introducción.- 2. Las manifestaciones de violencia hasta los conflictos de 1475-1476.3. El clero catedralicio durante los conflictos de 1475-1476.-4. La intensificación de los enfrentamientos a fines del siglo XV.- 5. Conclusión.- 6. Bibliografía citada.

\section{INTRODUCCIÓN}

La consideración de la Edad Media como una de las épocas históricas violentas por excelencia constituye, sin duda, uno de los tópicos historiográficos más fuertemente arraigados, todavía hoy en día, en el imaginario colectivo de las sociedades occidentales. En cualquier caso, y aunque, según ha destacado Claude Gauvard, los términos "violencia" y "violento" se usaron poco en la Edad Media, relacionándose sobre todo con un caso particular de violencia -la violación de una doncella-2 ${ }^{2}$, lo cierto es que la violencia, entendida ésta según las múltiples acepciones que el concepto tiene en la actualidad, fue un fenómeno muy presente, pero no necesariamente más que en otras épocas, en las sociedades medievales, algo perfectamente explicable si se tiene en cuenta la estrecha conexión que durante el Medievo hubo entre la violencia y realidades fundamentales de la sociedad como fueron la guerra, la caballería, la conflictividad política y los conflictos socioeconómicos, todo ello en un contexto ideológico en el que el propio tema de la violencia fue frecuentemente objeto de reflexión intelectual en la obra de muchos de los grandes pensadores, sobre todo eclesiásticos, de la época ${ }^{3}$.

Pero la violencia, al estar tan integrada en la sociedad medieval, también podía constituir un resorte necesario para la conservación de una determinada cohesión social y grupal. En definitiva, la violencia podía ser, y de hecho

C. Gavard, Violencia, p. 812.

3 El estudio de la violencia en la Edad Media cuenta con una larga tradición historiográfica, tanto a nivel europeo como en el ámbito hispánico. De entre la abundante bibliografía existente sobre el tema cabe destacar, entre otros muchos, algunos trabajos publicados en los últimos años, bien de carácter general o centrados en alguna dimensión específica de la violencia, como los de C. Barralis, F. Foronda, B. Sère (eds.), Violences souveraines; W.C. Brown, Violence in Medieval Europe; J. Feather, The pen and the sword; M. Aurell, T. Deswarte (eds.), Famille, violence; C. Gauvard, Violence et ordre public; D. Barthélemy, Chevaliers; R.W. Kaeuper (ed.), Violence. Respecto a la producción de la reciente historiografía española, hay que destacar la labor desarrollada por el Centro de Historia del Crimen de Durango y la revista "Clío \& Crimen", así como las obras de autores como, entre otros, I. Bazán, Delincuencia y criminalidad; R. Córdoba, El homicidio; J. M. Mendoza, Delincuencia y represión; R. Narbona, Malhechores; F. Sabaté, La pena de muerte. A ello habría que añadir la obra colectiva recientemente coordinada por B. Arízaga y J. A. Solórzano, La convivencia. Algunas reflexiones críticas sobre el problema de la violencia en su dimensión historiográfica aparecen recogidas en el estudio de I. Alfonso, Los nombres de la violencia. 
lo era, un fundamento de las jerarquías y poderes sociales. Y aunque fue sobre todo la nobleza la que ejerció por su propia voluntad comportamientos violentos, lo cierto es que la violencia -incluido el homicidio- fue un fenómeno que, en diversa media, estuvo repartido por todas las capas y estamentos sociales, incluyendo también a la propia Iglesia y al estamento clerical. La lógica de la violencia comprendía desde la injuria verbal al gesto injurioso, y desde los golpes y las heridas a la muerte, viéndose todo ello favorecido por la presencia de tensiones y conflictos sociales a muy diferente escala.

En este contexto, la presencia de la violencia, en sus diferentes dimensiones y formas de manifestación, como elemento integrante de la proyección sociopolítica del clero medieval ha sido puesta de relieve por la reciente historiografía europea a través de trabajos de diferente alcance y contenido ${ }^{4}$. Para el ámbito hispánico medieval la violencia de y contra el clero también ha sido objeto, aunque no suficientemente, de una cierta atención, más a través de análisis parciales que mediante investigaciones globales sobre el tema ${ }^{5}$. En el presente trabajo me centraré en el estudio de las manifestaciones de violencia en el seno del estamento clerical burgalés durante el siglo $\mathrm{XV}^{6}$, cuando, como es bien sabido, la violencia constituyó un ingrediente esencial de la casi permanente conflictividad social y política que, en el transcurso de diferentes crisis, se produjo en la corona de Castilla. Para ello utilizaré fundamentalmente fuentes manuscritas, casi todas inéditas, procedentes del Archivo Catedralicio de Burgos, sobre todo de su sección de Registros de Actas Capitulares?

4 El tema, en su proyección eclesiástica, ha sido objeto de una reciente atención monográfica en la obra colectiva de G. Jaritz, A. Marinkovic (eds.), Violence, donde destaca la introducción historiográfica realizada por P.D. Clarke, The Medieval Clergy and Violence, pp. 3-16. Otros trabajos recientes sobre la materia son, por ejemplo, los de M. Soria-Audebert, La crosse brisée; N. Fryde, D. Reitz (eds.), Bischofsmord im Mittelalter.

${ }^{5}$ La cuestión, en mayor o menor medida, se aborda en trabajos como los de J. García, Galicia en la baja Edad Media; J. I. Martín, R. González, Lucha de bandos; A. Polanco, Violencia verbal; J.I. Ruiz de la Peña, Las ciudades de señorío eclesiástico; M.A. Marques, Casos de violência. Sobre el asesinato en 1402 de Juan Serrano, obispo de Sigüenza, muy posiblemente envenenado por mandato de Gutierre Álvarez de Toledo, puede verse el libro de J.M. Nieto, Un crimen en la corte. Las manifestaciones de violencia y conflictividad en el estamento clerical castellano, desde una perspectiva general y con una especial atención a su dimensión representativa, han sido analizadas por J. Díaz, Los conflictos del clero.

6 Durante las últimas décadas, y teniendo como precedente los eruditos trabajos publicados por el padre Luciano Serrano en la primera mitad del siglo XX, las diferentes líneas de investigación sobre la iglesia y clero secular de Burgos en la Edad Media han dado como resultado estudios en los que se analizan cuestiones tanto de índole institucional como socioeconómica. Cabe destacar, entre otros muchos, los de N. López, Don Luis de Acuña; H. Casado, La propiedad eclesiástica; L. Fernández, Alonso de Cartagena; G. Martínez, La Iglesia de Burgos; I. Rilova, Burgos; S. Guijarro, Antigüedad; idem, Jerarquía y redes; J. Díaz, Simbología y ritual; idem, Alonso de Cartagena; J.A. Solórzano, Concubinarios.

7 Como instrumento de consulta y búsqueda de la documentación medieval de la catedral burgalesa hay que destacar el trabajo de M. Vicario (dir.), Catálogo, en particular los vols. I 
Los testimonios de violencia en el clero burgalés nos remiten por un lado al clero catedralicio, y fundamentalmente a los miembros del cabildo de canónigos, tratándose de enfrentamientos entre clérigos que, aunque en ocasiones tuvieron una dimensión individual, muchas otras veces implicaron a un buen número de eclesiásticos que, agrupados en facciones, se enfrentaban violentamente por causas diversas, por lo que es necesario relacionar dichos enfrentamientos con los conflictos entre bandos y parcialidades y las múltiples manifestaciones de violencia que a lo largo del siglo XV se produjeron en numerosas ciudades del ámbito hispánico, y por supuesto en la propia ciudad de Burgos ${ }^{8}$. Por otro lado, la violencia también se produjo ampliamente dentro del clero parroquial, aunque el estudio de esta última cuestión lo desarrollaré en otro trabajo. A continuación, por tanto, me centraré en el análisis de los principales testimonios de violencia dentro del clero y cabildo catedralicios.

\section{LAS MANIFESTACIONES DE VIOLENCIA HASTA LOS CONFLICTOS DE $1475-1476$}

Durante la baja Edad Media el desarrollo de conflictos internos en el clero burgalés adquirió una especial intensidad y relieve en el ámbito urbano, donde las estructuras sociales eran más complejas y estaban sometidas a mayores tensiones, a la vez que eran también especialmente sensibles a los contextos de crisis política, y donde asimismo la propia jerarquización interna del estamento clerical se manifestaba de forma mucho más intensa que en el ámbito rural, en el que las diferencias intraestamentales del clero, aun existiendo, se mostraban de una forma más diluida. Es sin duda esta mayor complejidad social inherente al mundo urbano la que explica que sea sobre todo en la ciudad de Burgos, y particularmente dentro del clero catedralicio, verdadero microcosmos social, donde las manifestaciones de violencia -física y verbal- entre eclesiásticos adquieran un mayor peso, tanto cuantitativa como cualitativamente. En este punto es importante recordar que para el enjuiciamiento y castigo de este tipo de altercados los miembros del cabildo de

(395-1431), y II (1432-1552). El mencionado catálogo, a su vez, incorpora y amplía el anterior publicado por D. Mansilla, Catálogo documental. Pero ante todo hay que destacar el catálogo en red informatizado, accesible a través de la web de Caja Círculo: Obra Social-Archivo Histórico de la Catedral de Burgos.

8 En Burgos durante el siglo XV hubo violentas luchas de bandos y enfrentamientos entre distintas familias y linajes de la ciudad, cuestión que ha sido bien analizada en trabajos como los de Y. Guerrero, Orden público, o J. A. Bonachía, Poder, violencia, estudios en los que, entre otros asuntos, se destaca el importante papel que tuvieron las relaciones clientelares en el desarrollo de todos estos conflictos. 
la catedral, así como los capellanes del número, estaban exentos de la jurisdicción del obispo, quedando sometidos a la del propio cabildo, que aplicaba la justicia a través de unos delegados especiales, los llamados Jueces de las Cuatro Témporas, que eran nombrados periódicamente -a veces cada dos o tres meses- de entre las dignidades y canónigos, y que particularmente se encargaban de los delitos cometidos en la iglesia catedral ${ }^{9}$. El número de estos jueces solía ser siempre de cuatro, hasta que el 3 de septiembre de 1468 el cabildo estableció que fuesen tres, una dignidad y dos canónigos ${ }^{10}$. En caso de decretarse pena de cárcel, ésta tenía lugar generalmente en la que poseía el propio cabildo, la llamada cárcel del Comunal, mientras que en los delitos juzgados por el obispo el encarcelamiento de los clérigos sometidos a su jurisdicción se producía en la denominada Santa Pía. De la custodia de ambas se encargaba un carcelero.

Durante el siglo XV el cabildo catedralicio burgalés, al igual que los del resto de Castilla, estaba integrado por dignidades, canónigos, racioneros y mediorracioneros. Las dignidades eran el deán; el chantre; el tesorero; el maestrescuela, oficialmente sólo desde 1454; los arcedianos de Burgos, Valpuesta, Treviño, Briviesca, Lara y Palenzuela; y los abades de Foncea, Castrojeriz, San Pedro de Cervatos, Salas de Bureba, San Millán de Lara y San Quirce. Para el año 1396, además de las dignidades, también consta que había 50 canónigos, 16 racioneros y 18 mediorracioneros ${ }^{11}$, si bien las dignidades también solían ser titulares de una de las canonjías. Por debajo se encontraban otros miembros del clero catedralicio, entre los que habría que destacar al importante colectivo de los llamados capellanes del número, que atendían los oficios litúrgicos en diferentes capillas de la catedral, y poseían sus propios estatutos y cargos internos, aunque también había otros capellanes que no formaban parte de este colectivo. A todos ellos se añadía un amplio y variopinto grupo de servidores del cabildo y del culto catedralicio, formado tanto por clérigos como por laicos: mozos de coro, sacristanes, sochantre, mayordomos,

9 El nombre asignado a estos jueces hace alusión a las denominadas Témporas, que en la Iglesia católica eran breves ciclos litúrgicos que se correspondían con el inicio de las cuatro estaciones del año, y que estaban consagrados particularmente a la penitencia y a la oración. Es precisamente ese carácter penitencial y de arrepentimiento asociado a las Témporas la razón que explica el nombre de estos jueces, encargados del castigo de los delitos cometidos por los miembros del cabildo. En la iglesia burgalesa frecuentemente se producían choques entre la jurisdicción episcopal y la del cabildo. Es lo que sucedió, por ejemplo, en 1470, cuando el 30 de diciembre de dicho año el cabildo apeló una sentencia de excomunión decretada por García Rodríguez de la Mota, canónigo y provisor del obispo, contra Pedro de Aranda, arcediano de Palenzuela, Juan Fernández de la Iglesia, su portero, y Bartolomé Alonso, capellán del número, pues según el cabildo desde tiempo inmemorial era a sus jueces a quienes les correspondía juzgar los delitos cometidos en el coro de la iglesia. ACB, Libro 49, ff. 5r-6v.

10 ACB, Registro de Actas 18, ff. $157 \mathrm{v}-158 \mathrm{r}$.

11 S. Guijarro, Antigüedad, pp. 68-70. 
campaneros, organista, maestro de capilla, relojero, porteros, carcelero e incluso un perrero.

Los testimonios de violencia más explícitos comienzan a aflorar en la década de los años treinta del siglo XV. El primero hace referencia a cómo el lunes 2 de abril de 1431 el canónigo burgalés Diego de Mendoza intentó atacar y matar con hombres armados al doctor Ivo Moro, arcediano de Lara, mientras éste se encontraba en su huerta en las afueras de Burgos, obligándole a huir precipitadamente a la ciudad y a refugiarse en los palacios episcopales. La narración de los hechos recogida en las Actas Capitulares resulta muy ilustrativa:

Paresçió y presente el doctor don Ivo Moro, arçediano de Lara, e dixo en como ayer lunes, que fue a dos días del dicho mes, año sobredicho, estando folgando en su huerta que veniera a él Diego de Mendoça, canónigo en la dicha eglesia, con omes armados para le desonrrar, e desque esto viera que se saliera por la otra puerta e se fuera fasa la çibdad de Burgos fuyendo, e le corriera el dicho Diego e los que con él venían con sus armas fasta que le ençerraron en los palaçios del obispo de Burgos, corriendo en pos del por le matar ${ }^{12}$.

Un día después de que acaecieran estos hechos Ivo Moro solicitó al cabildo catedralicio que, al tratarse de un asunto de su competencia jurisdiccional, realizase una pesquisa y averiguación sobre todo lo sucedido, lo que finalmente se encomendó a los canónigos Pedro García de Quintanavides y Juan González de Yeles. Y el sábado 7 de abril Ivo Moro, dado que había sido asas notorio e manifiesto el tumulto e escándalo e ruydo que Diego de Mendoça, canónigo, avía puesto el miércoles que pasó, que fue a quatro días del dicho mes, en la dicha eglesia, instó de nuevo al cabildo a que se realizase la pesquisa requerida para conocer la verdad de lo acaecido, a lo que el cabildo accedió $^{13}$, aunque desconocemos si finalmente Diego de Mendoza fue castigado por los graves hechos de los que se le acusaba.

Hay que llamar la atención sobre los orígenes familiares del mencionado canónigo, pues pertenecía a una rama de los Mendoza, linaje que durante estos años mantuvo en Burgos frecuentes enfrentamientos con muchos miembros de la familia Cartagena-Santa María ${ }^{14}$, tratándose tan sólo de un ejemplo entre otros muchos, según se verá más adelante, de miembros del cabildo catedralicio

\footnotetext{
12 ACB, Registro de Actas 10, f. 8v. Una copia posterior de la misma pesquisa y acusación contra Diego de Mendoza está recogida en ACB, Libro 47, f. 526v.

13 ACB, Registro de Actas 10, f. 9r.

14 Sobre los enfrentamientos personales entre los Cartagena y los Mendoza en Burgos puede verse el mencionado trabajo de Y. Guerrero, Orden público, pp. 52-56.
} 
burgalés procedentes de familias de la nobleza señorial y oligarquía urbana ${ }^{15}$. En cuanto a los hombres armados que acompañaban al canónigo Diego de Mendoza, el hecho de que la documentación no haga ninguna referencia explícita a su condición de eclesiásticos ni de miembros del cabildo nos hace suponer que quizá se trataba de laicos sin duda afines y vinculados familiar o clientelarmente al mencionado canónigo. En cualquier caso, hay que recordar que en la legislación sinodal burgalesa, de acuerdo con lo decretado en algunos concilios de Castilla y en los concilios generales de la Iglesia ${ }^{16}$, se prohibía explícitamente que los clérigos llevasen armas, tal como ya había sido establecido por el obispo Juan Cabeza de Vaca (1407-1413) en el sínodo celebrado en abril de 1412:

Otrosí, ordenamos que los clérigos no trayan armas, ni anden con cavalleros en manera de escuderos, ni trayan lanças ni cuchillos luengos ni ballestas ni otras armas, salvo si tovieren miedo de muerte o en camino ${ }^{17}$.

Lo cierto es que algunos meses más tarde de los acontecimientos recién expuestos, concretamente el 17 de septiembre, Ivo Moro y Diego de Mendoza, este último por medio de un procurador -el racionero Alfonso Fernández de Viejarrúa-, pusieron en manos del obispo de Burgos, Pablo de Santa María, todos los debates e pleytos e contiendas que tenían pendientes sobre benefiçios e préstamos e costas e debates commo en otra qualquier manera, para que el prelado actuase como juez árbitro de dichos debates ${ }^{18}$.

15 Lope Hurtado de Mendoza, por ejemplo, ostentó el cargo de deán del cabildo catedralicio burgalés a lo largo de varias décadas durante la primera mitad del siglo XV. I. Rilova, Burgos, p. 331. Y en la segunda mitad de dicha centuria también encontramos en el cabildo catedralicio burgalés a Íñigo de Mendoza, arcediano de Huete (ACB, Registro de Actas 18, f. 28r: 1/06/1467) y al canónigo Lope de Mendoza (ACB, Libro 46, f. 488r: 11/03/1485). En el siglo XV formarían parte del cabildo catedralicio diferentes eclesiásticos procedentes de familias nobiliarias y de la oligarquía urbana como los Manrique, Mendoza, Velasco, Cartagena, Acuña, Sandoval, Guzmán, Osorio, Carvajal o Maluenda, entre otras. L. Serrano, Los Reyes Católicos, p. 25. Sobre los orígenes nobiliarios de gran parte del alto clero castellano en la baja Edad Media puede verse el trabajo de J. Díaz, La incorporación de la nobleza. También está documentada, fundamentalmente a partir del siglo XV, la presencia de otros eclesiásticos procedentes de las distintas ramas del linaje Mendoza en diferentes cabildos catedralicios castellanos, como los de Santiago, Calahorra, Cuenca o Toledo, donde ocuparon sobre todo dignidades catedralicias. Ibidem, pp. 583-589.

16 Durante el siglo XV, y hasta 1503, en el obispado de Burgos se celebraron al menos once sínodos diocesanos. Su contenido aparece publicado en A. García (dir.), Synodicon, vol. VII, pp. 42-282. La legislación de estos sínodos se fundamentaba en gran medida en las disposiciones emanadas de los diferentes concilios provinciales celebrados con anterioridad en Castilla, que a su vez se basaban necesariamente en la legislación general de la Iglesia recogida en la actas del fundamental IV Concilio de Letrán de 1215, en las Decretales de Gregorio IX de 1234 y en otras compilaciones posteriores.

17 Ibidem, p. 149. Esta misma prohibición fue reiterada por el obispo Pablo de Santa María (1415-1435) en un sínodo celebrado durante los últimos años de su pontificado. Ibidem, p. 176.

18 ACB, Registro de Actas 9, f. 92r. 
Años después, concretamente en 1447, el canónigo Diego de Mendoza protagonizaría otro serio y violento altercado, en esta ocasión con el beneficiado y mayordomo del cabildo Alfonso Fernández de Busto, quien el 6 de enero de dicho año compareció ante los canónigos exponiendo cómo

estando salvo e seguro en la dicha eglesia, non fasiendo nin disiendo por qué mal nin daño deviesse aver, que veniera a él Diego de Mendoça, canónigo en la dicha eglesia, e le diera una bofetada en la cara e posiera mano a un bollón para le ferir o matar.

Por este motivo el mencionado mayordomo pidió que se castigase a Diego de Mendoza según correspondiese de derecho. El cabildo intervino mandando a este último que, so pena de un recésit de cinco años, no volviese a actuar contra Alfonso Fernández y que permaneciese en su casa hasta que se realizase una inquisición sobre lo sucedido, nombrando a continuación como jueces pesquisidores al abad de Foncea y a los canónigos Juan González de Yeles y Pedro Gutiérrez de Vivar ${ }^{19}$. Una vez realizada la pesquisa, el miércoles 11 de enero el cabildo, aplicando su competencia en la jurisdicción criminal del asunto, y considerando que Diego de Mendoza había injuriado y deshonrado a Alfonso Fernández de Busto en grand deshonra e vituperio de la dicha eglesia e de los benefiçiados della, condenó a dicho Diego de Mendoza al pago de un yantar para el cabildo, así como a no poder entrar en la iglesia de Burgos ni poder cobrar las distribuciones y pitanzas de su prebenda durante dos años ${ }^{20}$. No obstante, menos de un mes más tarde, el 6 de febrero, el obispo Alonso de Cartagena, declarándose competente al respecto, decidió absolverle de las penas impuestas por el asunto de la bofetada ${ }^{21}$.

Otro testimonio que tenemos sobre estas actitudes violentas de Diego de Mendoza nos lleva ya al año 1461, cuando cruzó ciertas "palabras injuriosas" con el canónigo Juan Garcés de Maluenda, por lo que el 10 de abril de dicho año el cabildo condenó al primero al pago de 1000 maravedís para un yantar y una misa de paz, y al segundo a pagar 800 maravedís ${ }^{22}$. Hay que señalar que Juan Garcés de Maluenda, sobre el que pronto volveremos, pertenecía a uno de los más importantes linajes de la oligarquía urbana burgalesa, el de los Alonso de Burgos-Maluenda, quienes durante el siglo XV desarrollaron numerosas actividades mercantiles, ostentando también cargos importantes en

19 ACB, Registro de Actas 3, f. 180r.

20 Ibidem, f. $180 \mathrm{v}$.

21 Ibidem, f. $181 \mathrm{v}$.

22 ACB, Registro de Actas 16, f. 244r. Este tipo de casos de violencia verbal entre canónigos también están documentados en otros cabildos catedralicios castellanos. Puede verse al respecto el ya mencionado trabajo de A. Polanco, Violencia verbal, pp. 373-380. 
el concejo y en el cabildo catedralicio de la ciudad ${ }^{23}$. Tres años después nos encontramos con otra noticia sobre este tipo de actitudes, cuando el 2 de marzo de 1464 el beneficiado Pedro de Velasco escribió al cabildo quejándose de haber sido agraviado por Diego de Mendoza ${ }^{24}$.

Dejando ya los violentos y reiterados altercados protagonizados por este último, y volviendo atrás en el tiempo, otro caso de violencia verbal entre miembros del cabildo catedralicio lo encontramos el 24 de julio de 1433, cuando se condenó a Pedro García de Olmillos, racionero, al pago de un yantar, así como a no entrar en la catedral durante un mes, por haber pronunciado "algunas palabras injuriosas" contra el cabildo ${ }^{25}$. Y el 10 de diciembre del mismo año los jueces de las Cuatro Témporas tomaron declaración a varios beneficiados como testigos de las palabras deshonestas e injuriosas pronunciadas en el coro por Lucas Sarmiento, racionero, en una disputa que tuvo con los capellanes del número ${ }^{26}$.

Dada la frecuencia con que se producían estos altercados violentos en la catedral burgalesa, no es de extrañar que los obispos legislasen al respecto en los sínodos diocesanos. Por ejemplo Pablo de Santa María (1415-1435) estableció en una constitución sinodal, datada con posterioridad al año 1428, la pena de excomunión para quien causara heridas a otra persona en el interior del templo catedralicio o en sus claustros:

Otrosí, por quanto en la nuestra yglesia cathedral siempre por la mayor parte hay gran concurso de gente, por lo qual muchas vezes acaescen en ella muchos ruydos e contiendas, de que se siguen injurias e presumpciones, por ende la dicha nuestra yglesia, a quien debe ser acatada mayor reverencia que a otra yglesia alguna de nuestro obispado, muchas vegadas está violada e es necesario de se frequentar las reconciliaciones. Por ende, por evitar estos peligros e otros mayores que desto se podrían seguir, ordenamos e establecemos, aprobante la santa synodo, que qualquier que feriere a otro en la dicha nuestra yglesia cathedral o en qualquier de sus claustras, que, allende del sacrilegio que por la dicha razón cometiere e, otrosí, de las penas establecidas en el derecho, incurra en sentencia de excomunión por ese mismo fecho, de la qual no pueda ser absuelto sino por nuestro señor el papa o por nos o por nuestros sucesores ${ }^{27}$.

23 Sobre este linaje, que estaba emparentado con los García de Santa María, hay que destacar el trabajo de H. Casado, Una familia.

24 ACB, Registro de Actas 17, f. 178v.

25 ACB, Libro 47, f. 527r.

26 ACB, Registro de Actas 7, f. 100r-v.

27 A. García (dir.), Synodicon, vol. VII, p. 176. 
Cuando los conflictos acaecían no ya entre personas individuales, sino entre grupos de eclesiásticos que, encabezados por algún canónigo, se enfrentaban muy violentamente y de forma reiterada entre sí, entonces se hacía necesario el establecimiento de una tregua formal con el fin de tratar de poner freno a las hostilidades. Es lo que sucedió, por ejemplo, el 27 de septiembre de 1437, cuando el cabildo ordenó a los canónigos Gil Gómez de Yanguas y Juan López de Castro que estableciesen una tregua e segurança entre sus hombres, familiares y comensales, llegándose finalmente a un acuerdo de tregua hasta el próximo día de Año Nuevo, bajo pena de quinientos florines para quien la quebrantase:

los señores deán e cabillo de la dicha eglesia...dixeron que, por quanto avía avido ruydo e escándalo e cochilladas entre los omes de Gil Gómes de Yanguas, canónigo, de la una parte, e los omes de Juan Lópes de Castro, canónigo, de la otra parte, e porque non se recreçiesse más insulto e daño los dichos señores dixeron que de su ofiçio mandavan e mandaron a los sobredichos e a cada uno dellos que se otorgassen tregua e segurança, que non se fisiessen mal nin daño el uno al otro, e que esta tregua e segurança otorgassen por sy e por sus familiares continuos comensales. E luego los sobredichos e cada uno dellos dixeron que otorgavan e otorgaron la dicha tregua e segurança fasta el día de Año Nuevo primero seguiente ${ }^{28}$.

Son varias las consideraciones que cabe hacer respecto al conflicto recién aludido. Primeramente, hay que llamar la atención sobre la doble función de la violencia en cuanto que elemento integrador y de cohesión grupal dentro de cada bando clerical, a la vez que también actuaba como un explícito instrumento de exclusión con respecto a los integrantes del bando contrario. Por otro lado, las expresiones "omes de" y "familiares continuos comensales" nos conducen ante los claros vínculos clientelares de los integrantes de cada grupo hacia los canónigos que estaban al frente de los mismos, pudiendo tratarse tanto de eclesiásticos como quizá también, y a la vez, de algunos de sus servidores laicos, lo que nos muestra la existencia de complejas, y a veces enfrentadas, redes de solidaridad interna en el seno del clero catedralicio. Finalmente, puede observarse cómo en esta época en la documentación todavía no se emplea el término "violencia" ni sus derivados para referirse a todos estos altercados, utilizándose en su lugar otros términos como "ruydo", "escándalo", "cochilladas" o "insulto e daño". Los dos primeros términos recién aludidos, además, ponen de manifiesto la gran importancia que tenía la opinión

28 ACB, Registro de Actas 10, f. 110r. 
pública, algo evidente en una cultura como la medieval, donde la información se transmitía prioritariamente por vía oral.

Volviendo ahora al ya mencionado canónigo Juan Garcés de Maluenda, hay que señalar que el 3 de enero de 1455 el cabildo catedralicio le condenaría al pago de 100 maravedís de multa por haber discutido en la iglesia con el canónigo Pedro Guerra, a quien se condena a pagar 500 maravedís, destinándose en este caso el montante de ambas multas a sufragar las obras en curso del Hospital de Rey ${ }^{29}$. Y cuatro años después, el 11 de julio de 1459 , tras haberse informado por el testimonio de varios canónigos acerca de ciertas palabras injuriosas que al parecer dicho Juan Garcés había cruzado con Pedro de Aranda, deán de Oviedo, no respetando así la reverencia debida al cabildo, éste decidió reprender públicamente a ambos, y especialmente a Juan Garcés por haber sido quien comenzó la disputa, si bien algunos canónigos testificaron que, a su juicio, las palabras que cruzaron no fueron en realidad "criminosas" ni "injuriosas". De todas formas hay que llamar especialmente la atención sobre el hecho de que en este caso el cabildo consideró que para echar pena, que segund el estatuto era poca, que era mucho mejor la reprehensión que non la pena..., que se emendasen e de aquí adelante las semejantes palabras çesasen (...) por quanto segund el estatuto la pena era pequeña e la verguença les cargaría más ${ }^{30}$, cobrando así una mayor importancia la pública recriminación por un comportamiento indebido y poco acorde con el respeto que la institución capitular requería, máxime por parte de sus propios miembros.

Algunos meses antes tenemos noticia de otro altercado, en este caso protagonizado por el canónigo Juan Ortiz de Frías, a quien el cabildo catedralicio, el 15 de diciembre de 1458, mandó que se le tomase declaración por haber abofeteado y agredido, con intención de quitarle una espada, al molinero Juan de Salas, requiriendo a este último para que, si tuviese testigos, los presentase, tras lo cual el notario del cabildo, Pedro Rodríguez de Belorado, tomó a Juan Ortiz dicha declaración, mandándole que non fisiese movimiento alguno por sy nin por sus parientes nin por otra persona, e que otro día sábado venyese a la eglesia porque los señores se informasen, a lo que el mencionado canónigo accediós ${ }^{31}$.

En otras ocasiones los protagonistas de los conflictos eran algunos capellanes de la catedral. Por ejemplo, el 26 de diciembre de 1458 Diego Martínez, procurador del cabildo catedralicio, mandó guardar prisión en su casa,

29 ACB, Registro de Actas 14, f. 133r.

30 ACB, Registro de Actas 16, ff. 109v-111r.

31 ACB, Registro de Actas 16, f. 69r. 
por indisciplina, al capellán del número Juan Alonso el Rojo, a lo que éste se opuso enérgicamente señalando que aquél no tenía competencia jurisdiccional sobre él ${ }^{32}$. No obstante, tres días más tarde el cabildo catedralicio ordenó a dicho Juan Alonso no salir de su casa durante ocho días sin licencia previa ${ }^{33}$, y el 1 de febrero de 1459, cumplida ya la pena que se le había impuesto, se le mandó asimismo pedir perdón públicamente ante todos los miembros del cabildo por las faltas cometidas ${ }^{34}$. Tan sólo cinco días después, el 6 de febrero, el cabildo ordenó en esta ocasión a Juan de Laredo, capellán de la Visitación, permanecer en la cárcel del Comunal por haber abofeteado en la sacristía al capellán Juan Sánchez de Beatalva ${ }^{35}$, imponiéndosele finalmente, el 15 de febrero, la condena de diez días de prisión en el Comunal, prohibición de entrar en la catedral durante veinte días, pago de 400 maravedís, que se destinarían a una misa de paz, y petición pública de perdón al capellán agredido ${ }^{36}$.

Estas peticiones de perdón y la celebración de misas de paz fueron también algo habitual entre los propios canónigos del cabildo catedralicio burgalés, tratándose de actos que estaban revestidos de una fuerte dimensión ritual. Así, el cabildo había dispuesto en 1452 la aplicación de fuertes multas destinadas a misas de paz cuando los enfrentamientos entre canónigos tuviesen lugar durante la celebración de la misa en la catedral o mientras se rezaban las horas canónicas, estableciendo que quien dijese palabras injuriosas contra algún beneficiado fuese castigado al pago de 1000 maravedís, que se repartirían al día siguiente en una misa de paz entre los asistentes a la misma ${ }^{37}$. Otras veces los miembros del cabildo catedralicio celebraban reuniones de reconciliación con el objetivo de reestablecer la concordia entre los canónigos que estaban enfrentados, quienes debían perdonarse mutuamente. Una de estas reuniones se celebró el 26 de marzo de 1464, aunque en esta ocasión algunos beneficiados se negaron a perdonar a quienes habían simulado estar enfermos para poder cobrar las rentas que les correspondían por el rezo de las horas, a pesar de haberse ausentado ${ }^{38}$.

Dos años atrás, el 11 de octubre de 1462, los jueces de las Cuatro Témporas pronunciaron varias condenas contra miembros del cabildo y

32 ACB, Registro de Actas 16, f. 66r.

33 Ibidem, f. 79r-v.

34 Ibidem, f. 81r.

35 Ibidem, ff. $83 \mathrm{v}-84 \mathrm{r}$.

36 Ibidem, f. 85r.

37 I. Rilova, Burgos, pp. 359-360.

38 "Otrosy, todos los señores se reconçilliaron e se dieron pas e se perdonaron los unos a los otros por reverençia de Dios e porque Dios los perdonase", aunque respecto al cumplimiento del deber de asistencia al rezo de las horas dijeron "que non perdonavan los que se avyan fecho apuntar por enfermos non lo seyendo". ACB, Registro de Actas 17, f. 182r. 
clero catedralicio en relación con actos de violencia verbal. Primeramente condenaron al canónigo Pedro Girón, hermano del obispo Acuña, al pago de 1000 maravedís de multa, debido a que dicho canónigo, reaccionando contra la expulsión unos días antes de un mozo de coro criado suyo, había dicho que

pesase a quien pesase, que él le metería al dicho moço en el coro...que él juraba a Dios que al mayor de la iglesia cascaría la cabeça...desiendo que juraba a Dios que, pues echaban pena, que no dexaría de descalabrar a cualquier dignidad o canónigo de la iglesia, aunque supiese perder la calongía...e aun dixo que no dexaría de faser matar dos o tres canónigos ${ }^{39}$.

Y el mismo día condenaron a Sancho Sánchez de Prestines, arcediano de Lara, a pagar 200 maravedís por proferir injurias contra el cabildo, así como al canónigo Juan Sánchez de Bilbao y al capellán del número Pedro Sánchez Lubero a pagar, respectivamente, 100 y 50 maravedís por haberse insultado en el coro, mandando además que dicho Pedro Sánchez estuviese tres días en la cárcel del Comunal ${ }^{40}$. Tan sólo dos días después los jueces condenaron nuevamente a Sancho Sánchez de Prestines, en esta ocasión a pagar 700 maravedís por haberse insultado con el mayordomo Juan Alonso, a quien asimismo se le impuso una multa de 300 maravedís $^{41}$.

No cesarían aquí los incidentes en que se vio involucrado el arcediano de Lara, pues el 13 de julio de 1470 se tomó declaración a varios testigos de un grave altercado mantenido entre el mencionado arcediano y el protonotario Juan Manrique, en el que también se vieron involucrados caballeros armados de ambas partes. Tras las declaraciones de los testigos, se puso una multa de 8000 maravedís al protonotario, condenándole al destierro hasta fines de agosto, y se ordenó a ambos contendientes que no volviesen a pelear, so pena del pago de 30.000 maravedís y un año de destierro ${ }^{42}$. La participación en el violento altercado de hombres armados apoyando a cada una de las partes da una clara idea del respaldo clientelar laico con que contaban determinados miembros del cabildo catedralicio, aproximando en cierto modo el conflicto a las luchas entre bandos urbanos.

39 N. López, Don Luis de Acuña, p. 257 (ACB, Registro de Actas 17, f. 53r).

40 ACB, Registro de Actas 17, f. 53r.

${ }^{41}$ Ibidem, f. 53v.

42 ACB, Registro de Actas 18, ff. 311r-313v. 


\section{EL CLERO CATEDRALICIO DURANTE LOS CONFLICTOS DE 1475-1476}

Cuando a las tensiones internas entre los miembros del clero catedralicio que venimos describiendo se unía un incremento de la conflictividad urbana en contextos de crisis política, entonces el clima de violencia latente podía llegar al punto de que la vida de algunos canónigos corriese peligro. Es lo que sucedió en 1475, durante los momentos preliminares de la guerra civil por la sucesión al trono castellano, cuando, el jueves 15 de junio, el cabildo catedralicio mandó que se apuntara como presentes a los beneficiados que por los escándalos que avya en esta çibdad (...) les era peligroso de estar en la çibdad (...) por reçelo que tenyan de sus personas, siempre y cuando no estuviesen en contra de la causa del rey Fernando, a quien el día anterior, estando el monarca presente en Burgos, los miembros del cabildo habían jurado lealtad y permanecer en su serviçio ${ }^{43}$

Hay que llamar la atención sobre el hecho de que, al poner el cabildo como condición para apuntar en el coro a los ausentes su juramento de lealtad al rey Fernando, estaba a la vez reconociendo la falta de unidad entre todos los canónigos a la hora de adherirse a la posición política a favor de la reina Isabel que el cabildo había adoptado en los momentos preliminares de la guerra civil de sucesión al trono castellano. En efecto, unos días antes Fernando de Aragón había entrado en la ciudad de Burgos, en un contexto claramente prebélico durante el que Isabel y Fernando, antes de que el rey de Portugal entrara en Castilla, se dispusieron a preparar la defensa. Para ello se repartieron la tarea de desplazarse personalmente, aunque por separado, a distintas ciudades, ya que convenía asegurarse el envío de tropas ciudadanas para engrosar la hueste que Fernando estaba organizando. Era imprescindible, por tanto, asegurar la fidelidad de las ciudades que habían alzado pendones a su favor, antes de poner a prueba dicha fidelidad con demandas militares. Por este motivo las ceremonias de entrada real y otros ritos de compromiso mutuo, como los juramentos y homenajes, resultaban especialmente apropiados en esta coyuntura prebélica. El rey Fernando, tras haber visitado Salamanca, Zamora y Valladolid, se dirigió a Burgos ${ }^{44}$. La entrada que realizó en la ciudad debió ser particularmente solemne, a juzgar por los gastos empleados, pues parece que se invirtió en el recibimiento al monarca la considerable suma de 300.000 maravedís. Fernando, al igual que había hecho días atrás en Salamanca, exigió al concejo burgalés y a sus oficiales que le jurasen de nuevo como rey y le prometieran de nuevo obediencia. Lo mismo hizo con el cabildo

43 ACB, Registro de Actas 20, f. 25r.

44 A.I. Carrasco, Isabel I, p. 153. 
catedralicio, obligando a cada uno de los canónigos a jurarle personalmente obediencia. A continuación el monarca dispuso los preparativos para el cerco del castillo. Hay que tener muy en cuenta que el obispo Luis de Acuña (14561495), quien ya en 1464 se había declarado partidario del príncipe Alfonso frente a Enrique $\mathrm{IV}^{45}$, ahora seguía el partido juanista y la obediencia del rey de Portugal desde su residencia en la fortaleza de San Cristóbal, en Rabé de las Calzadas, y que el castillo de Burgos, bajo el mando de Íñigo de Stúñiga, también seguía este partido ${ }^{46}$, dirigiéndose desde él muchos ataques contra los habitantes de la ciudad ${ }^{47}$.

Por ello se explica que al día siguiente de que se realizase el mencionado juramento el cabildo dispusiese, para favorecer el mantenimiento de la paz y evitar posibles altercados en el seno de la institución, que se ausentasen de la ciudad los canónigos más afines al obispo Acuña: el arcediano de Burgos, Fernando Díez de Fuentepelayo, que había sido mayordomo del prelado; el hermano de éste y arcediano de Valpuesta, Pedro Girón; Martín Vázquez de Acuña, también pariente suyo; Juan Osorio, arcediano de Treviño y sobrino del obispo; el maestro Gómez de Santa Gadea y el maestrescuela Alfonso López de Béjar, familiares del prelado. El cabildo les consideraría como presentes a la hora de cobrar sus emolumentos si, según se señaló antes, no se mostraban contrarios a la causa del rey Fernando y residían en un lugar fiel al monarca $^{48}$.

En este contexto, en la señalada reunión capitular del 15 de junio de 1475 , el cabildo puso en manos de sus letrados, para que se informasen al respecto, el caso concreto del canónigo Lope de Rojas sobre el que, no habiendo realizado todavía el mencionado juramento de lealtad al rey, los beneficiados Juan Alonso y Luis Garcés de Maluenda declararon que se le debía apuntar puesto que non avya osado venir a la eglesia por miedo que non le matasen, a lo que otros canónigos sin embargo respondieron diciendo que non avya

45 J.M. Nieto, Iglesia y génesis, p. 277.

46 A.I. Carrasco, Isabel I, p. 157.

47 Según señala Luciano Serrano, a fines de mayo el rey Fernando ya supo que el castillo de Burgos se había rebelado, mientras que la ciudad se mantenía fiel a él y a la reina Isabel. En el castillo se refugiaron, entre otros, miembros destacados de la familia Stúñiga, muchos caballeros a su servicio, y Antonio Sarmiento, que era uno de los alcaldes de Burgos y hermano del obispo Acuña. Los acogidos en el castillo sumaron pronto unos cuatrocientos, y antes de finalizar el mes de mayo ya dirigían contra la ciudad disparos de artillería, simultaneados con ataques a mano armada, saqueo de víveres y correrías por toda la comarca. Las autoridades municipales burgalesas pusieron en conocimiento de los monarcas todos estos hechos, pidiéndoles el envío de fuerzas para poner cerco al castillo, por lo que finalmente el propio rey Fernando tomó la decisión de acudir a Burgos para asegurarse la fidelidad de su población y preparar el cerco del castillo. L. Serrano, Los Reyes Católicos, pp. 144-145.

48 Ibidem, pp. 145-146. 
rasón de lo puntar pues él andava en roydos e en vandos, siendo esto último negado por los mencionados Juan Alonso y Luis Garcés, quienes dijeron que non andava en vandos e lo fasía en ayuda de su padre ${ }^{49}$. Sabemos que Lope de Rojas era hijo del regidor Pedro de Cartagena, perteneciendo por tanto al linaje judeoconverso de los Santa María-Cartagena, y lo cierto es que durante estos meses fue uno de los rebeldes a Isabel y Fernando ${ }^{50}$, por lo que ya en marzo se había ordenado su destierro de la ciudad ${ }^{51}$, habiendo sufrido también la prisión y el destierro años atrás por su participación en disturbios diver$\operatorname{sos}^{52}$. Además, los Rojas estaban emparentados con el obispo Acuña, también desleal a los monarcas ${ }^{53}$. A pesar de todo, no es de extrañar que el beneficiado Luis Garcés de Maluenda saliese en su defensa frente a las acusaciones que se realizaban contra él, dados los vínculos personales y de parentesco que había entre los Maluenda y los Cartagena. Todo ello, en definitiva, viene a ser una clara muestra de las redes clientelares, grupos de oposición y tensiones internas que se daban en el seno del cabildo catedralicio, y ello aparte de la tensión latente que en ese momento, por razones obvias, había entre gran parte del cabildo y el obispo Luis de Acuña.

El asedio del castillo de Burgos duró cerca de ocho meses, y a la financiación de la lucha tuvieron que contribuir muy significativamente tanto el concejo de la ciudad como el cabildo catedralicio, siendo este último obligado por el rey Fernando a vender diversos objetos de oro y plata de su patrimo-

49 ACB, Registro de Actas 20, f. 25r.

50 L. Serrano, Los Reyes Católicos, p. 146.

51 ACB, Registro de Actas 20, f. 13r.

52 Lope de Rojas figura desde 1457 como racionero en el cabildo catedralicio burgalés. $\mathrm{ACB}$, Registro de Actas 16, f. 6r. Una prueba de su carácter belicoso y afición a las armas viene dada por el hecho de que el 8 de febrero de 1465, siendo ya canónigo, su padre Pedro de Cartagena expuso ante el cabildo que su hijo partía para luchar en la guerra contra el turco, solicitando que se le apuntase como residente, a lo que el cabildo accedió inicialmente por un plazo de cuatro meses. ACB, Registro de Actas 17, ff. 268v-269r. Ya el 16 de abril del año anterior el propio Lope de Rojas había expresado personalmente ante el cabildo su deseo de marchar a luchar contra el turco. ACB, Registro de Actas 17, f. 185 r. El 15 de febrero de 1465, aunque con ciertas reticencias, el cabildo decidiría considerarle como residente por el plazo de un año. Ibidem, f. 271v. En abril del año siguiente ya había regresado de la guerra, pues vuelve a aparecer en las reuniones del cabildo. Ibidem, f. 379 r. El 13 de agosto de 1470 Lope de Rojas fue condenado por el cabildo a permanecer preso en la casa del arcediano de Treviño hasta nuevo mandamiento, por el alboroto que causó al llevarse a Juan de Puentedura, hombre bueno de la ciudad, que había sido apresado por Martín de Prestines, entrometiéndose así en la jurisdicción eclesiástica y civil. Un día después de este incidente, el cabildo le condenaría a un mes de destierro, sin compensación económica alguna, y al pago de 1000 maravedís de multa, mandándole permanecer encerrado en casa de su padre hasta el viernes, en que debía partir al destierro. ACB, Registro de Actas 18, ff. 321r-322v. No obstante, el 4 de septiembre, antes de haber transcurrido dicho mes, el cabildo le levantaría la pena de destierro, permitiéndole volver a la ciudad y entrar en la iglesia. Ibidem, f. $327 \mathrm{v}-328 \mathrm{r}$.

53 L. Serrano, Los Reyes Católicos, p. 27. 
nio ${ }^{54}$. Los hombres del castillo, a cuyo frente estaba Antonio Sarmiento, hermano del obispo, habían tomado también una iglesia que se encontraba en sus proximidades, la de Santa María la Blanca, encastillándola a modo de fortaleza y cometiendo desde ella todo tipo de robos, desmanes e incluso asesinatos. Según nos narra el cronista Fernando del Pulgar, en ayuda del rey Fernando acudieron su hermano bastardo Alfonso de Aragón, duque de Villahermosa; el conde de Haro; Alfonso de Arellano, conde de Aguilar; los caballeros Pedro Manrique y Sancho de Rojas; el capitán Esteban de Villacreces; y otros caballeros y hombres de armas de la comarca ${ }^{55}$. Siguiendo la narración que nos hace Pulgar, el rey

continuó sienpre el çerco del castillo de Burgos, e acordó de conbatir aquella iglesia de Santa María la Blanca, que hera muy çercana al castillo, porque entendió que tomada aquella iglesia se podría mejor e más presto aver la fortaleza. E fizo adereçar sus conbates por seys partes, con tiros de pólvora e ballestería, e un día por la mañana començaron a llegar los pertrechos e a conbatir aquella iglesia...E duró aquel conbate por espaçio de seys oras, en las quales no pudo ser tomada, por la gran defensa que fizieron los que estavan en la iglesia, con los pertrechos muchos e tiros de pólvora que tenían. Por lo qual, e porque el rey vido muchos muertos e feridos de los suyos, e que cada hora ferían más, mandó retraer su gente, con propósito de la tomar a conbatir con más pertrechos e con gente de refresco, e çesó el conbate por estonçe ${ }^{56}$.

Como puede verse, los combates eran violentos, con un claro protagonismo de la artillería. Finalmente los que estaban refugiados en la iglesia, cerca de cuatrocientos según el cronista, dados los heridos y bajas que tenían, optaron por entregar la iglesia al monarca, que pudo así a partir de este momento presionar mucho más a quienes continuaban refugiados en el castillo ${ }^{57}$. A comienzos de 1476, tras este duro asedio y combates, las tropas fernandinas lograron la rendición del castillo, que durante estos meses había estado siendo sostenido por parientes del duque de Arévalo. Esta victoria sería decisiva en la marcha de la guerra, alejándose así la amenaza francesa que hacía peligrar la frontera guipuzcoana. El 10 de enero la reina Isabel realizó la que sería su primera entrada solemne en Burgos, y para la ocasión el concejo, a pesar de lo castigado que estaba económicamente, desplegó toda la pompa que pudo:

54 N. López, Don Luis de Acuña, p. 269. Sobre la historia del castillo burgalés puede verse M. Sainz (coord.), Seminario sobre el Castillo de Burgos.

55 F. del Pulgar, Crónica, vol. I, pp. 150-151.

56 Ibidem, p. 153.

57 Ibidem, p. 154.

ANUARIO de Estudios Medievales, 43/2, julio-diciembre 2013, pp. 543-576 ISSN 0066-5061, doi:10.3989/aem.2013.43.2.02 
rogocijos públicos, juegos, música y danza. El 23 de enero, fiesta de San Ildefonso, la reina juró ante el concejo de la ciudad, en la misma iglesia de San Ildefonso, en el momento de alzar la hostia consagrada, que no entregaría el castillo al duque de Arévalo ni a ningún otro noble ni caballero, conservándolo para la corona. Dado que en la ciudad había muchos partidarios de los portugueses, la reina ordenó algunas ejecuciones públicas que exhibieron su mano justiciera ${ }^{58}$.

Respecto al obispo Luis de Acuña, hay que tener presente que su postura inicial decididamente contraria a los monarcas durante el comienzo de su reinado no se correspondía con la actitud general manifestada por la Iglesia castellana durante la crisis política de estos primeros años, actitud en la que predominó ante todo el sometimiento a la autoridad regia de Isabel y Fernando ${ }^{59}$. Por ello se explica que, tras la caída del castillo en manos de los monarcas, el prelado siguiese en su fortaleza de Rabé, con prohibición expresa de entrar en Burgos. Allí continuó durante más de cinco años, conforme a las severas disposiciones de los monarcas contra sus adversarios políticos. En mayo de 1476 el concejo burgalés prohibió expresamente, bajo pena de muerte, que se vendiesen armas o caballos a los hombres del obispo que estaban desterrados ${ }^{60}$, y en agosto los del municipio mandaron escribir una carta dirigida al prelado quejándose de que sus hombres habían intentado matar a un vecino de la ciudad ${ }^{61}$. Por fin en 1479 se firmó la paz con Portugal, y los monarcas acordaron perdonar a cuantos en Castilla habían favorecido la causa portuguesa, incluyendo, por supuesto, al obispo Acuña. Pero hasta fines de marzo de 1481 el prelado no manifestaría sus deseos de regresar a Burgos, a lo que la ciudad accedió, siendo recibido solemnemente por el cabildo ${ }^{62}$.

En cuanto al canónigo Lope de Rojas, en junio de 1476 el rey Fernando le perdonó disponiendo que, pese a la actitud rebelde que había mostrado contra él y la reina, pudiese residir en la ciudad con sus familiares, pues había jurado estar al servicio de los monarcas, dando al parecer ciertas garantías de cumplir el juramento ${ }^{63}$. No obstante, Lope de Rojas no vivió mucho tiempo más. El 5 de noviembre de 1477 designó cabezaleros testamentarios, para que

58 A.I. Carrasco, Isabel I, pp. 193-195.

59 J.M. Nieto, Iglesia y génesis, pp. 287-288. Una clara expresión del predominio del apoyo de la Iglesia castellana a los monarcas fue la cooperación que se produjo, en general, por parte de la Iglesia en el pago de un empréstito solicitado de ella por los reyes en 1476 para asegurar la financiación de los distintos frentes militares y políticos abiertos al comenzar su reinado. Ibidem, p. 288.

60 Archivo Municipal de Burgos, Actas de 1476, ff. 26v-27v.

61 Ibidem, f. 60v.

62 N. López, Don Luis de Acuña, p. 271.

63 L. Serrano, Los Reyes Católicos, p. 192. 
en su nombre pudieran disponer de sus bienes tras su muerte, al racionero Luis Garcés de Maluenda, a fray Juan de San Martín, prior del convento dominico de San Pablo de Burgos, y al maestro Gómez ${ }^{64}$. El día 14 del mismo mes ya había fallecido, pues el cabildo se reunió para decidir qué hacer con los beneficios que había dejado vacantes tras su muerte ${ }^{65}$, y el 11 de diciembre se leyó su testamento, donde mandaba ser enterrado en la capilla mayor del convento de San Pablo ${ }^{66}$, que estaba bajo el mecenazgo de los Cartagena.

\section{LA INTENSIFICACIÓN DE LOS ENFRENTAMIENTOS A FINES DEL SIGLO XV}

Situándonos ya en los años ochenta del siglo XV, hay que señalar que se trata sin duda de la década en que, por los testimonios documentales conservados, se produjeron más altercados violentos protagonizados por los miembros del clero catedralicio. Las noticias comienzan el 13 de marzo de 1481, cuando en el cabildo se planteó si se debía castigar a Sancho Sánchez de Frías, sochantre, por haber injuriado de palabra manifiestamente a Pedro Martínez Gadea, decidiéndose finalmente que, puesto que le había pedido perdón, no se le aplicaría ninguna pena, a lo que el tesorero del cabildo añadió que, dado que el sochantre se quejaba de que "abía algunos que murmuraban del e de sus compañeros", debían cesar de inmediato las murmuraciones de algunos canónigos sobre el altercado ${ }^{67}$. Esto último nos remite de nuevo, según ya se señaló páginas a atrás, a la importancia de la oralidad y la opinión pública en la cultura medieval.

Dos años más tarde, el lunes 18 de agosto de 1483, Pedro Girón, arcediano de Valpuesta, el licenciado Frías y el bachiller Juan Martínez, canónigos, como jueces de las Cuatro Témporas, condenaron al canónigo Luis González Palomeque a pagar 100 reales de plata, y al canónigo Gonzalo de Maluenda 50 reales, por las ofensas e palabras e cosas injuriosas y gestos ynjuriosos que el día anterior, domingo, se habían dicho en el coro de la catedral, discusión tras la cual el mencionado Luis González Palomeque había llegado a amenazar en su casa a Gonzalo de Maluenda con ombres armados para lo acuchillar. Previamente a la imposición de esta condena, en la capilla de Santa Catalina de la catedral, el deán y los canónigos que estaban allí re-

64 ACB, Volumen 48, f. 323r.

65 ACB, Registro de Actas 20, f. 127v.

66 ACB, Volumen 48, ff. 323r-325v. En el testamento Lope de Rojas hizo, entre otras muchas, donaciones a la Trinidad y la Merced, para redención de cautivos; al convento de San Pablo; a las emparedadas de la ciudad de Burgos; a su hija Mencía de Rojas, a quien dejó 60.000 maravedís; y al cabildo catedralicio, a quien cedió los derechos de los frutos de su canonjía.

67 ACB, Registro de Actas 22, f. $263 \mathrm{v}$. 
unidos requirieron a ambos inculpados para que, en un gesto revestido de una evidente dimensión simbólica y representativa,

luego se abraçasen e diesen paz e fuesen buenos amigos, los quales luego se abraçaron, e así mismo el dicho señor deán les dio a amos a dos paz e los abraçó e los otros señores. E esto así fecho, luego los dichos señores les mandaron que de aquí adelante fuesen buenos amigos como era la razón, so pena que por la primera vez que riñesen mandaron que fuesen puestos en reçésit de un año cada uno dellos, e más ca allende estobiesen un año en el çepo ${ }^{68}$.

Tres meses después, el 12 de noviembre del mismo año, tenemos noticia de un nuevo altercado, en esta ocasión entre el canónigo Fernando Sánchez de Medina y el capellán del número Diego de Aranda. La causa de la disputa en cuestión fue un tanto pintoresca, a juzgar por las declaraciones presentadas dicho día ante los jueces capitulares por los testigos que la presenciaron. El primero fue el tundidor Fernando de Medina, quien bajo juramento declaró que el pasado domingo había visto al canónigo Fernando Sánchez de Medina en la ventana de su casa, y al capellán Diego de Aranda en la ventana de la casa del canónigo Fernando de Aranda, y que Fernando Sánchez y Diego de Aranda discutían acerca de una silla que alguien había sacado de casa del primero sin su permiso. Al parecer Fernando Sánchez había dicho que si viese al que sacó la silla que le descalabraría o fisiera descalabrar, a lo que Diego de Aranda había respondido con poca paçiençia disiendo que quien la sacara hera tan bueno e mejor que non él, además de decir otras palabras, por lo que al testigo declarante le paresçió el dicho Diego de Aranda estar más desmesurado e exçeder contra el dicho Ferrando Sánchez e ser más culpable.

Otro testigo fue el canónigo Fernando de Aranda, quien dijo que en el momento en que empezó la discusión no se encontraba presente, sino que llegó cuando Diego de Aranda y Fernando Sánchez de Medina ya estaban voceándose, y que este último dijo a aquél anda para vellaco o soys vellaco, y otras palabras que no recordaba, respondiendo Diego de Aranda yo soy tan bueno e mejor que non vos. El siguiente testigo, el racionero y sochantre Sancho Sánchez de Frías, declaró que había oído a Fernando Sánchez de Medina decir a Diego de Aranda que a él e a quien quiera que hallara tomando la sylla que le quebrantaría la cabeça, a lo que Diego de Aranda respondió señalando que no le abía miedo a él ni a todo su linaje, tras lo cual Fernando Sánchez había replicado vos quién soys, y Diego de Aranda había respondido mas vos quién soys, agravándose después la discusión, motivo por el cual el propio

68 ACB, Registro de Actas 33, f. 138r-v. 
testigo Sancho Sánchez de Frías había subido a la casa donde se encontraba Diego de Aranda a cerrar la ventana porque no exçediesen más en palabras.

El último testigo al que se tomó declaración y juramento fue Pedro de Barruelo, criado del canónigo Fernando Sánchez de Medina, y declaró que este último había dicho que sy viera llevar la sylla que diera con ella al que la llevaba, a lo que Diego de Aranda respondió que quiçá le diera él con ella, a lo que Fernando Sánchez replicó que se fuese para el diablo, respondiéndole de nuevo el otro que se fuese él para el diablo, que non le abía myedo e que presumía mucho, que de tan buen linaje hera como él, continuando luego la discusión en similares o peores términos ${ }^{69}$.

De las declaraciones de los antedichos testigos, sobre todo de los dos últimos, y al margen de lo irrelevante y casi anecdótica que pueda parecer la razón del inicio de la disputa -el robo de una silla-, se desprende que en el fondo del conflicto subyacía la pretendida preeminencia social del canónigo Fernando Sánchez de Medina sobre el capellán del número Diego de Aranda, y ello aparte de la gran distancia que en la jerarquía catedralicia separaba a un canónigo, miembro por excelencia del cabildo catedralicio, de un simple capellán. Hay que tener en cuenta que los Medina, ya desde fines del siglo XIV, eran un importante linaje de la élite de poder burgalesa, gracias a lo cual ocuparon relevantes cargos municipales ${ }^{70}$. Es así como adquieren pleno sentido la excesiva presunción de linaje que se le reprochó al mencionado canónigo y el vos quién soys que el tercer testigo puso en boca de ambos contendientes, siendo todo ello una clara muestra de que para estos últimos, a pesar de su condición de eclesiásticos, parecía tener mucha más importancia la pertenencia a un determinado linaje de la sociedad burgalesa.

Un mes más tarde de que se tomara declaración a los antedichos testigos, el 17 de diciembre, el arcediano de Treviño y los canónigos Martín Vázquez de Acuña y Juan García de Medina, como jueces de las Cuatro Témporas nombrados al efecto por el cabildo, pronunciaron su sentencia condenando al capellán Diego de Aranda al pago de doscientos maravedís, y a Fernando Sánchez de Medina al pago de cien maravedís. Además, el mismo día los antedichos jueces también condenaron al deán del cabildo Alonso de Barajas a pagar mil maravedís de multa por, entre otras cosas, las palabras rigurosas $e$ desonestas que había dicho a dos capellanes al expulsarlos del coro, así como

69 ACB, Registro de Actas 33, ff. 146r-147r. Algunos años atrás Fernando Sánchez de Medina, siendo racionero, ya había sido castigado con motivo de algún altercado violento. Así, por ejemplo, el 31 de marzo de 1478 fue condenado por los jueces de las Cuatro Témporas a pagar 150 maravedís por injuriar a un sastre y a Andrés, clérigo de San Esteban. ACB, Registro de Actas 20, f. 149v.

${ }^{70}$ Y. Guerrero, Rey, nobleza y élites, p. 258. 
por las palabras ynjuriosas que había dirigido contra el escribano del cabildo y contra otros miembros de la corporación ${ }^{71}$.

A pesar de estos intentos por parte del cabildo de poner freno a la violencia verbal entre los miembros del clero catedralicio, poco después afloran en la documentación otras noticias sobre este tipo de altercados. Así, el 28 de enero de 1484 los nuevos jueces de las Cuatro Témporas -el arcediano de Lara Sancho Sánchez de Prestines y los canónigos Fernando Sánchez de Frías y Gonzalo de Maluenda- impusieron las siguientes penas: de nuevo al deán, por unas palabras deshonestas que dijo en el coro al sochantre, le condenaron a pagar diez reales de plata; al racionero Juan de San Juan, por las palabras injuriosas que dirigió en el coro, a la hora de Vísperas, contra el sacristán Juan Fernández, también diez reales; al canónigo Fernando Sánchez de Medina, por las voces que dio en el coro injuriando al deán señaladamente, diziendo que no hera para regir e poniendo lengua en los otros señores, cinco reales ${ }^{72}$.

Algunas semanas más tarde, el 19 de febrero, los jueces de las Cuatro Témporas impondrían nuevas penas a varios canónigos por sus excesos verbales: a García López, por las palabras injuriosas que varios días atrás dijo en el coro a Juan Alonso, diez reales; a Gadea, por dar grandes voces en el coro y no haber obedecido al deán cuando le mandó callar, respondiéndole con gran soberbia, cinco reales; a Martín Vázquez de Acuña, sobrino del obispo, también por dar voces en el coro y haber respondido "furiosamente" al capiscol cuando le mandó callar, tres reales; nuevamente al orgulloso canónigo Fernando Sánchez de Medina, por haber dicho reiteradamente, a voces y de forma despectiva abaxo, ruynes a los racioneros y mediorracioneros cuando, al asignársele lugar en el coro a alguna nueva dignidad o canónigo, aquéllos se tenían que desplazar hacia abajo en sus asientos, reprochando airadamente a uno de ellos que él hera mejor que no él, e valía más que él e tenía más que él y que callase mucho en hora mala, le castigaron a pagar cinco reales; al arcediano de Valpuesta, porque sin causa alguna se había dirigido al capiscol diciéndole don capiscolito, soys vos el que andays en estas cosas, cien maravedís; y finalmente, por la renzilla e palabras desonestas e ynjurias que se dixeron los unos a los otros e por el alboroto que fisieron en el cabillo semanas atrás, condenaron al arcediano de Valpuesta a pagar 465 maravedís, al arcediano de Treviño 30 reales, al tesorero 20 reales, y al provisor Juan Daza 30 reales $^{73}$.

71 ACB, Registro de Actas 33, f. 147r.

72 Ibidem, f. 149r.

73 Ibidem, ff. 149r-150r.

ANUARIO de Estudios Medievales, 43/2, julio-diciembre 2013, pp. 543-576 ISSN 0066-5061, doi:10.3989/aem.2013.43.2.02 
$\mathrm{Al}$ año siguiente tenemos noticia de un grave incidente en el que indirectamente aparecen implicados algunos miembros del cabildo catedralicio. Así, el 12 de febrero de 1485, se expuso ante el cabildo cómo un tal Fernando de Frías, laico que estaba excomulgado por haber dado palos y herido a un clérigo presbítero al que descalabró en la cabeça que le fizo salir sangre, y que era primo del sochantre Sancho Sánchez de Frías y del canónigo Fernando Sánchez de Frías, había acudido el día anterior al templo catedralicio durante el rezo de las Vísperas y, al ser recriminado por el canónigo Juan Alonso, vicario del obispo, para que saliera, pues estaba excomulgado, le había hecho ademanes de manos e con la espada que tenía çeñida e disiéndole palabras desonestas. Al negarse a salir, veyendo su revelldía e desonestidad e poco temor de Dios nuestro señor, el mencionado vicario se había dirigido al coro pidiendo a los presentes que cesaran de inmediato el rezo de las horas para no incurrir en suspensión, cosa que, "obedientes a los mandamientos de la iglesia", hicieron todos los beneficiados excepto el sochantre, quien con un grupo de capellanes y los mozos de coro decidió continuar, llegando a rezar incluso las Completas, por lo que dicho sochantre y los capellanes que le secundaron incurrieron en suspensión. Tras este incidente Fernando de Frías, delante de la casa del canónigo Pedro Martínez Gadea, y ante otros canónigos, les dixera que descreya de Dios e de la fee e de la crus sy no le dava de palos al que avya dicho que el sochantre estava descomulgado, refiriéndose al canónigo Fernando Sánchez de Medina, que allí estaba presente, y diciendo que pues los canónigos se amenasaban con palos unos a otros non hera mucho que los diese él, acusación de la que el mencionado Fernando Sánchez de Medina se había defendido señalando que lo que él había dicho era que porque el sochantre abía dicho e fecho desir las horas que creya estava suspenso e no sabía sy abía yncurrido en excomunión. Por todos estos hechos, el cabildo prohibió que en adelante dicho Fernando de Frías fuese defendido y acogido en sus casas por sus parientes capitulares antes mencionados, so pena de un mes de recésit para estos últimos, encargando además a sus jueces que castigasen al sochantre, por haberse negado a interrumpir el rezo de las horas, y que también impusieran alguna pena ejemplar al canónigo Fernando Sánchez de Frías, por las palabras deshonestas que había dicho en el cabildo a favor de su primo desiendo que el clérigo a quien avya dado los palos no merescía aquello, mas cortarle dos dedos de la lengua. Dos días más tarde, y al continuar las amenazas de Fernando de Frías al cabildo, éste extendió a todos los beneficiados la prohibición de acogerle en sus casas y de hablar con él, ordenándole además presentarse en la cárcel de Santa Pía para someterse a la jurisdicción episcopal, y permanecer en 
ella preso fasta que los dichos señores en uno con los señores vicarios manden soltarle ${ }^{74}$.

De los hechos recién expuestos se desprende la mayor importancia que algunos canónigos otorgaban a la solidaridad familiar y de linaje frente a sus deberes eclesiásticos y frente a una supuesta solidaridad interna dentro del cabildo que a menudo no se respetaba, dadas las frecuentes tensiones que había entre sus miembros, y ello hasta el punto de perder el miedo a las consecuencias que acarreaba una pena de suspensión. En el caso del linaje Frías, que tenía un peso notable en la élite de poder burgalesa, con una nutrida representación en el regimiento ${ }^{75}$, todo esto resulta evidente en el conflicto que se acaba de describir. Fernando de Frías, al estar excomulgado por haber agredido a un clérigo ${ }^{76}$, y de acuerdo con lo prescrito por la normativa canónica, no podía recibir los sacramentos ni entrar en iglesia alguna ni estar presente en la celebración de los oficios divinos, debiendo ser exhortado a salir de la iglesia en caso de no respetar esta prohibición. Además, el excomulgado no podía hablar con los miembros de la comunidad cristiana ni éstos con él ${ }^{77}$. Así se explican las disposiciones del cabildo catedralicio prohibiendo a sus miembros acoger a Fernando de Frías o hablar con él, o el mandato a los beneficiados de interrumpir el rezo de las horas al negarse Fernando de Frías a salir de la catedral, so pena de una suspensión canónica que conllevaba la privación temporal del uso del oficio eclesiástico y de las rentas beneficiales.

Por otro lado es muy relevante, desde el punto de vista de la percepción de las tensiones sociales urbanas, el claro conocimiento que el laico Fernando de Frías tenía de los actos de violencia que protagonizaban los propios canónigos, que según sus palabras se amenasaban con palos unos a otros, y ello aparte de la reiterada violencia verbal manifestada precisamente, según hemos visto antes, por el canónigo Fernando Sánchez de Medina, hacia quien Fernando de Frías había dirigido también sus amenazas.

En otras ocasiones la documentación nos proporciona también información sobre actos de violencia verbal por parte de algunos capellanes. Así,

74 ACB, Registro de Actas 22, ff. 206v-207v. En las constituciones del sínodo que el obispo burgalés Juan Cabeza de Vaca celebró el 15 de septiembre de 1411, en el apartado dedicado a la sentencia de excomunión, se señala que esta última es "medicina de las ánimas de aquellos que la temen e obedecen, e es pecado mortal en aquellos que la menosprecian", indicándose que los legos excomulgados recalcitrantes deben ser llevados presos a la cárcel de Santa Pía. A. García (dir.), Synodicon, vol. VII, pp. 147-148.

75 Y. Guerrero, Rey, nobleza y élites, p. 256.

76 Las Partidas, basándose en la legislación canónica, recogen claramente la pena de excomunión para todo laico que agrediese a un clérigo con intención de herirle o matarle. G. López (ed.), Las Siete Partidas, Primera Partida, Título IX, Ley III. El Título IX de la Primera Partida está dedicado por entero a las penas de excomunión, suspensión y entredicho.

77 Á. Marzoa, La censura de excomunión, p. 113. 
por ejemplo, el 20 de septiembre de 1486, el cabildo encargó a los jueces de las Cuatro Témporas que se informasen sobre cierto insulto que al parecer Juan Sánchez de Moneo, capellán del número, dirigió a una mujer que había sido criada del prior Pedro Pardo, ya fallecido, y en caso de encontrarle culpable le aplicasen el oportuno castigo ${ }^{78}$.

$\mathrm{Al}$ año siguiente se produjeron unos duros enfrentamientos entre varios miembros del cabildo catedralicio. Así, el 5 de marzo de 1487, este último mandó encerrar y encadenar en la cárcel del Comunal por ellos ser muy dignos de grand castigo como porque a otros fuese enxiemplo a Jerónimo de Lerma, arcediano de Palenzuela, y a los canónigos Francisco de Torquemada y García López de Prestines, que la noche anterior se habían peleado entre ellos con escándalo...muy ynorme e grave en la calle de San Llorente, armados con escudos y lanzas, llegando el mencionado arcediano y sus hombres a herir gravemente en una mano al escudero Juan de Rozas:

andando los dichos Françisco de Torquemada e Garçía Lópes de Prestines, canónigos, de noche çerca de media noche por la cal de Sant Llorente, armados muy desonestos cantoneando, el dicho señor arçediano saliera a ellos con gente armada e con lanças e escudos e les acometieran e maltrataran, espeçialmente al dicho Garçía Lópes de Prestines...que sy no fuera por estar muy armado le mataran, e a un escudero del señor prothonotario de Lara que yba con él, que se llama Juan de Roças, cortaran la mano derecha por la muñeca de manera que quedara del todo manco o se le cortara, de lo qual los dichos señores ovieron grand dolor e sentimiento, asy por el daño recreçido a las partes e que puede resultar adelante sy no se ataja con la ayuda de Dios, como por lo que dello han que desir e se dirá por la çibdad e otras partes, e la culpa general que a todos se echará e dirán ${ }^{79}$.

Ante la extrema gravedad de los hechos descritos, el cabildo comisionó al deán Alonso de Barajas y a los canónigos Juan Sánchez de Bilbao y Juan Sánchez de la Puebla para que hiciesen una pesquisa detallada de todo lo sucedido, imponiendo a los culpables un castigo merecido y ejemplarizante para los demás. Llama particularmente la atención, además de la gran violencia del altercado, el temor expresado por el cabildo acerca de las negativas consecuencias que el incidente podría tener en la opinión pública: por lo que dello han que desir e se dirá por la çibdad e otras partes, e la culpa general que a todos se echará e dirá. De ahí la necesidad de imponer a los culpables un castigo que a otros fuese enxiemplo.

78 ACB, Registro de Actas 28, f. 89v.

79 ACB, Registro de Actas 28, f. 113r-v. 
Tres días después, el 8 de marzo, en el transcurso de la pesquisa sobre lo acaecido, se tomó declaración a numerosos testigos del incidente, tanto laicos como eclesiásticos, cada uno de los cuales tuvieron que responder a un cuestionario de cinco preguntas ${ }^{80}$. Finalmente, el 4 de abril el cabildo comisionaría a García Ruiz de la Mota, capiscol, al tesorero Luis Garcés de Maluenda y a Gonzalo de Puentedura, abad de Castrojeriz, para que se encargasen de imponer una paz y tregua entre los canónigos implicados en el violento conflicto, así como entre sus parientes, castigando a quienes no la respetasen ${ }^{81}$.

No obstante, en cuanto a su intención ejemplarizante, de poco sirvieron estas medidas correctivas tomadas por el cabildo, pues el 16 de diciembre del mismo año de 1487 tenemos noticia del "escándalo e turbación" que en la tarde de ese día acaeció entre Fernando Díez de Fuentepelayo, arcediano de Burgos, Pedro Girón, arcediano de Valpuesta, el tesorero Luis Garcés de Maluenda, Gonzalo de Puentedura, abad de Castrojeriz, y el canónigo Lope de Mendoza, motivado por las palabras de enojos que ovieron los unos contra los otros platicando sobre el negoçio de la jurisdicción. Para evitar nuevos escándalos Juan Sánchez de Bilbao, canónigo y secretario del cabildo, en nombre de éste, requirió a los antedichos para que guardasen una tregua hasta el día de Año Nuevo, tregua que finalmente se comprometieron a aceptar ${ }^{82}$.

En el fondo, detrás de todo el escándalo susodicho subyacía una división interna en el cabildo catedralicio entre partidarios y opositores del obispo Luis de Acuña ${ }^{83}$, a lo que se añadía la pretensión de este último de extender el ejercicio de su jurisdicción al cabildo, lo que iba en contra de la multisecular exención con respecto a la justicia episcopal de que el cabildo había gozado hasta entonces. Para complicar aún más la situación, en este juego de intereses jurisdiccionales el propio cabildo estaba dividido, pues algunos deudos y parientes del obispo favorecían sus pretensiones, agudizándose así la tensión interna y las amenazas entre los miembros de la corporación capitular. Dado el desarrollo que estaban tomando los acontecimientos, Acuña hizo llegar a los monarcas una denuncia sobre el tipo de vida que llevaban algunos canónigos y los graves enfrentamientos que había entre los mismos. Por este motivo, el 22 de diciembre de 1487, los Reyes Católicos encargaron a Juan Pereira, arcediano de Nájera, que fuese a Burgos para informarse sobre las diferencias que había entre el obispo y el cabildo, tratando de poner paz y sosiego entre ambas partes, y procurando averiguar secretamente si en realidad el obispo tenía algún tipo de potestad jurisdiccional sobre el cabildo. En el documento

80 ACB, Registro de Actas 27, ff. 450-462b.

81 ACB, Registro de Actas 28, f. 116r-v.

82 ACB, Registro de Actas 27, ff. 313v-314r.

83 N. López, Don Luis de Acuña, pp. 244-245. 
regio también se expone que, a causa de dichas diferencias, algunos delitos cometidos por los canónigos no habían podido ser castigados adecuadamente, a lo que se añadían los problemas derivados de estar muchos canónigos emparentados entre sí, a la vez que el obispo también tenía muchos parientes en el cabildo y en la ciudad, lo que podría motivar algunos escándalos e ruydos de lo qual a nos se podría segyr deservyçio e a la dicha çibdad daño ${ }^{84}$.

En realidad no les faltaba razón a los monarcas, ni al obispo Acuña, al cuestionar la correcta aplicación de la justicia sobre los miembros del cabildo catedralicio, pues pocos días antes, el 19 de diciembre, había sido elegido como juez de las Cuatro Témporas el polémico canónigo Fernando Sánchez de Medina, que estaba enfrentado, según hemos visto páginas atrás, con varios miembros del cabildo, motivo por el cual algunos capitulares no aprobaron dicha elección ${ }^{85}$. Y, por otro lado, el 26 de septiembre de 1488 encontraremos ejerciendo el mismo cargo nada menos que al arcediano de Palenzuela, Jerónimo de Lerma, protagonista el año anterior del grave enfrentamiento armado que ya se ha descrito ${ }^{86}$. Teniendo en cuenta los precedentes de ambos y los muchos enemigos que tenían en el cabildo, no cabe menos que poner muy en duda su imparcialidad en el ejercicio de la justicia capitular.

De todas formas, y ante el peligro de que la intervención regia pudiese acabar de forma definitiva con su exención jurisdiccional, el cabildo catedralicio decidió llegar a una primera avenencia con el obispo el 6 de mayo de 1488, aceptando la sentencia en el pleito que los jueces compromisarios nombrados por ambas partes habían pronunciado el pasado 23 de abril en el palacio de los condestables de Castilla. Es el llamado Laudo, confirmado de forma específica por Inocencio VIII el 19 de febrero de $1489^{87}$. En este acuerdo, aunque se mantenía la exención jurisdiccional del cabildo, se permitía también al obispo intervenir junto al cabildo en la corrección de los delitos más graves ${ }^{88}$. Quizá pueda verse, asimismo, una cierta voluntad conciliadora en el nombramiento de jueces de las Cuatro Témporas que el cabildo realizó el 18 de diciembre de ese mismo año de 1489, pues el cargo en esta ocasión recayó en el capiscol García Ruiz de la Mota, hombre de dilatada experiencia en su desempeño, y en el canónigo Juan Martínez de Astudillo, que era además secretario del obispo Acuña ${ }^{89}$.

84 AGS, Registro General del Sello, XII-1487, f. 157.

85 ACB, Registro de Actas 27, f. 324v.

86 ACB, Registro de Actas 28, f. 310v.

87 ACB, Vol. 13/2, ff. 225r-233v. La sentencia del 23 de abril está también recogida en ACB, Libro 46, ff. 10r-12v, y la confirmación de Inocencio VIII en ff. 9r-13v.

88 N. López, Don Luis de Acuña, p. 245.

89 ACB, Registro de Actas 29, f. 146v. 
Pero lo cierto es que el prelado continuó insatisfecho con este primer acuerdo, por lo que las discusiones continuaron durante los dos años siguientes, alcanzándose un nuevo momento de tensión el 30 de septiembre de 1491, cuando el cabildo se opuso a que el canónigo Martín Vázquez de Acuña y Fernando Díez de Fuentepelayo, arcediano de Burgos, ambos familiares del obispo Acuña, fuesen elegidos jueces de las Cuatro Témporas, elección que, de haber salido adelante, habría supuesto al menos una forma indirecta de control del prelado sobre la corporación capitular. Ese mismo día, además, el arcediano de Lara, Sancho Sánchez de Prestines, Gonzalo de Burgos, abad de San Quirce, y otros beneficiados se negaron a aceptar las propuestas en torno al tema de la jurisdicción presentadas por los partidarios del obispo Acuña, y tampoco admitieron una misa de paz que quería celebrar el prelado ${ }^{90}$.

Ante el desarrollo de los acontecimientos los monarcas tuvieron que intervenir nuevamente en el pleito, y el 10 de octubre de 1491 se dirigieron a Andrés de Ribera, alcaide de Burgos, y a los oficiales de justicia del concejo, para que amparasen y defendiesen al obispo Acuña en su derecho, ratificado por el papa, a juzgar junto con el cabildo los delitos más graves cometidos por los beneficiados, dado que el prelado se había quejado de que algunos miembros del cabildo obstaculizaban que pudiese ejercer su jurisdicción sobre ellos ${ }^{91}$. Y al año siguiente, el 24 de marzo de 1492, mandaron al obispo y cabildo que aplicasen correctamente su acuerdo de juzgar conjuntamente los delitos y excesos más graves cometidos por algunos canónigos, evitando así que estos pudiesen quedar impunes por no haber acuerdo sobre quién debía juzgarlos ${ }^{92}$.

Finalmente, el 10 de abril de 1492, se firmó una nueva concordia, en presencia del corregidor García de Cotes y del inquisidor apostólico Alonso Juárez. En ella se estableció que el obispo y los jueces del cabildo juzgasen conjuntamente a aquellos prebendados que incurriesen, entre otros, en los delitos de blasfemia, homicidio, mutilación e injurias, mientras que los jueces capitulares, sin intervención del obispo, podrían dictar sentencias en aquellos delitos en que no interviniesen las armas ni hubiese derramamiento de sangre, en los juegos de dados con apuestas inferiores a 30 reales y en algunos casos de amancebamiento y adulterio ${ }^{93}$. Esta concordia sería conocida en lo sucesivo como concordia alejandrina, al ser aprobada el 29 de septiembre del mismo año por Alejandro $\mathrm{VI}^{94}$, quien nombró ejecutores de la misma a los abades de

90 ACB, Registro de Actas 29, f. 355r-v.

91 AGS, Registro General del Sello, X-1491, f. 205.

92 AGS, Registro General del Sello, III-1492, f. 414.

93 ACB, vol. 54, ff. 377r-381v; vol. 55/2, ff. 76r-81v; libro 46, ff. 95r-97v (copia simple).

94 ACB, vol. 55/2, ff. 61r-65v; libro 46, ff. 105r-107v (copia simple). 
San Pedro de Cardeña y San Pedro de Arlanza ${ }^{95}$, sirviendo de base para posteriores pleitos entre obispo y cabildo en torno al tema de la jurisdicción, pues los sucesivos prelados burgaleses se negaron a aceptar el considerable grado de exención jurisdiccional del que, en la práctica, todavía gozaría el cabildo ${ }^{96}$.

Ya para terminar señalaremos que, mientras se desarrolló el dilatado pleito jurisdiccional entre el obispo Acuña y el cabildo, este último continuó juzgando muchos de los delitos en que incurrían los canónigos. Así, por citar tan sólo algunos ejemplos, el 5 de abril de 1490 los jueces de las Cuatro Témporas hicieron una pesquisa sobre las palabras injuriosas que el arcediano de Burgos, Fernando Díez de Fuentepelayo, había dicho en el coro contra el canónigo Francisco Díez ${ }^{97}$, y el 27 de mayo impusieron al primero por tal motivo una condena de 200 maravedís $^{98}$. Y al año siguiente, el 19 de julio de 1491, castigaron al canónigo Martín Vázquez de Acuña a pagar 50 reales para una misa de paz, por haber protagonizado una disputa en el coro ${ }^{99}$.

\section{CONCLUSIÓN}

A lo largo de las páginas precedentes hemos tenido ocasión de analizar una amplia selección de testimonios de violencia en el seno del clero catedralicio burgalés, fundamentalmente entre miembros del cabildo de canónigos, tratándose de enfrentamientos entre eclesiásticos que, aunque en ocasiones tuvieron una dimensión individual, también muchas veces implicaron a varios clérigos que, agrupados en facciones, y contando en ocasiones con el respaldo de clientelas laicas, se enfrentaron violentamente por causas diversas, por lo que cabría relacionar en cierto modo dichos enfrentamientos con los conflictos entre bandos y parcialidades y las múltiples manifestaciones de violencia que a lo largo del siglo XV se produjeron en numerosas ciudades castellanas.

En estas últimas el mantenimiento del orden público, el ejercicio de la justicia y acabar con roydos, escándalos y bolliçios constituía una de las piezas clave del concepto de buen gobierno ${ }^{100}$. Para el caso de Burgos, durante el siglo $\mathrm{XV}$ tenemos constancia de frecuentes enfrentamientos, en ocasiones verdaderas luchas de bandos, entre las diferentes familias y linajes que constituían la

95 ACB, libro 46, ff. 108r-110v (copia simple).

96 N. López, Don Luis de Acuña, p. 246.

97 ACB, Registro de Actas 29, f. 173v.

98 ACB, Registro de Actas 28, f. 170r.

99 ACB, Registro de Actas 29, f. 337r-v.

100 Y. Guerrero, Rey, nobleza y élites, p. 250. 
élite de poder urbana, lo que el concejo intentó atajar mediante ordenanzas de justicia ${ }^{101}$. En 1486, por ejemplo, las actas concejiles recogen noticias sobre los frecuentes "ruidos y escándalos" que había, lo que ocasionaba una grand mengua e desonrra de la çibdad ${ }^{102}$. Lo habitual de estos episodios violentos se explica en un marco social en el que el recurso a la venganza y al desafío en los casos de afrenta familiar o privada se consideraba casi como un deber.

Una situación paralela a todo ello, y con muchos elementos de conexión, es la que vino dada por la violencia, tanto física como verbal, entre miembros del cabildo catedralicio, una gran parte de los cuales, según se ha visto, procedían a su vez de importantes familias de la nobleza y oligarquía urbana burgalesa, a menudo enfrentadas entre sí. Las motivaciones de los conflictos dentro del clero catedralicio fueron variadas, pudiendo señalarse razones personales, profesionales, clientelares, familiares y de pertenencia a una facción eclesiástica favorable o contraria al prelado diocesano, situación esta última que es particularmente patente en época del obispo Luis de Acuña. Ante estos conflictos, cuyo nivel de intensidad y violencia se incrementó en las décadas finales del siglo XV, sobre todo en los contextos de crisis sociopolítica, el cabildo catedralicio ejerció su potestad jurisdiccional tratando de poner freno, a menudo sin éxito, a las nefastas consecuencias que para el buen gobierno de la institución acarreaban los reiterados enfrentamientos entre sus miembros, aplicando castigos a los culpables y propiciando fórmulas rituales de reconciliación, como fueron las treguas, las misas de paz y las peticiones públicas de perdón.

No obstante, a fines de la década de los años ochenta, el escaso nivel de disciplina de ciertos canónigos, la radicalización de los enfrentamientos y la polarización de los miembros del cabildo entre partidarios y opositores al obispo Acuña motivaron que este último, alegando la necesidad de castigar con mucha mayor contundencia los delitos y crímenes de ciertos canónigos, pretendiese extender su potestad jurisdiccional al cabildo, en contra de la multisecular exención de que hasta entonces gozaba. La gravedad del conflicto que se desarrolló entre obispo y cabildo por el asunto de la jurisdicción hizo necesaria la intervención regia e incluso pontificia, llegándose finalmente a una avenencia que, reconociendo al cabildo el ejercicio de su propia jurisdicción, permitía al prelado intervenir, siempre junto a los jueces capitulares, únicamente en los delitos de mayor gravedad cometidos por los canónigos. De ahí que en épocas posteriores otros obispos luchasen de nuevo para lograr un aumento de su potestad jurisdiccional sobre el cabildo.

$101 \quad$ Ibidem, pp. 256-257.

102 Archivo Municipal de Burgos, Actas de 1486, f. 31r. Sobre el concepto del honor en la ciudad de Burgos véase el trabajo de J.A. Bonachía, "Más honrada que ciudad de mis reinos...". 
Finalmente, es importante recalcar que esta presencia de la violencia en las relaciones entre miembros del clero catedralicio nos sitúa de lleno en el ámbito urbano, donde las estructuras sociales eran más complejas y estaban sometidas a profundas tensiones, a la vez que eran también más sensibles a las crisis políticas, y donde asimismo la jerarquización interna del clero se manifestaba más intensamente que en el ámbito rural.

\section{BIBLIOGRAFÍA CITADA}

Alfonso, Isabel, Los nombres de la violencia y el control de su legitimación, "Hispania" 61/208 (2001), pp. 691-706.

Arízaga Bolumburu, Beatriz; Solórzano Telechea, Jesús Ángel (eds.), La convivencia en las ciudades medievales (Nájera, Encuentros Internacionales del Medievo 2007), Logroño, Instituto de Estudios Riojanos, 2008.

Aurell, Martín; Deswarte, Thomas (eds.), Famille, violence et christianisation au Moyen Âge, París, Presses de l'Université Paris-Sorbonne, 2005.

Barralis, Christine; Foronda, François; Sère, Bénédicte (eds.), Violences souveraines au Moyen Âge: travaux d'une école historique, París, PUF, 2010.

Barthélemy, Dominique, Chevaliers et miracles. La violence et le sacré dans la société féodale, París, Armand Colin, 2004.

Bazán Díaz, Iñaki, Delincuencia y criminalidad en el País Vasco en la transición de la Edad Media a la Moderna, Vitoria, Universidad del País Vasco, 1995.

Bonachía Hernando, Juan Antonio, "Más honrada que ciudad de mis reinos...". La nobleza y el honor en el imaginario urbano (Burgos en la baja Edad Media), en Bonachía Hernando, Juan Antonio (coord.), La ciudad medieval. Aspectos de la vida urbana en la Castilla bajomedieval, Valladolid, Universidad de Valladolid, 1996, pp. 167-212.

Bonachía Hernando, Juan Antonio, Poder, violencia y orden público en Burgos (1379-1433), en Martín Cea, Juan Carlos (coord.), Convivir en la Edad Media, Burgos, Dossoles, 2010, pp. 101-158.

Brown, Warren Curtis, Violence in Medieval Europe, Harlow, Longman, 2010.

Carrasco Manchado, Ana Isabel, Isabel I de Castilla y la sombra de la ilegitimidad. Propaganda y representación en el conflicto sucesorio (14741482), Madrid, Sílex, 2006.

Casado Alonso, Hilario, La propiedad eclesiástica en la ciudad de Burgos en el siglo XV: el cabildo catedralicio, Valladolid, Universidad, 1980. 
Casado Alonso, Hilario, Una familia de la oligarquía burgalesa del siglo XV: los Alonso de Burgos-Maluenda, en La ciudad de Burgos. Actas del Congreso de Historia de Burgos, Valladolid, Junta de Castilla y León, 1985, pp. 143-162.

Clarke, Peter D. The Medieval Clergy and Violence: An Historiographical Introduction, en Jaritz, Gerhard; Marinkovic, Ana (eds.), Violence and the medieval clergy, Krems, Central European University, 2011, pp. 3-16.

Córdoba de la Llave, Ricardo, El homicidio en Andalucía a fines de la Edad Media, Granada, Universidad, 2007.

Díaz Ibáñez, Jorge, La incorporación de la nobleza al alto clero en el reino de Castilla durante la baja Edad Media, "Anuario de Estudios Medievales" 35/2 (2005), pp. 557-603.

Díaz Ibáñez, Jorge, Simbología y ritual en torno a las relaciones y conflictos sociales del clero burgalés durante la baja Edad Media, "Espacio, Tiempo y Forma, Serie III, Historia Medieval" 22 (2009), pp. 91-121.

Díaz Ibáñez, Jorge, Los conflictos del clero en sus relaciones sociales e intraestamentales. Formas de representación, en Nieto Soria, José Manuel (dir.), El conflicto en escenas. La pugna política como representación en la Castilla bajomedieval, Madrid, Sílex, 2010, pp. 143-182.

Díaz Ibáñez, Jorge, Alonso de Cartagena y la defensa de la exención del obispado burgalés frente al primado toledano, "En la España Medieval" 34 (2011), pp. 325-342.

Feather, Jennifer, The pen and the sword: violence in late fifteenth and sixteenth-century texts, Providence, Brown University, 2006. (Tesis doctoral).

Fernández Gallardo, Luis, Alonso de Cartagena. Una biografía política en la Castilla del siglo XV, Valladolid, Consejería de Educación y Cultura, 2002.

Fryde, Natalie M.; Reitz, Dirk (eds.), Bischofsmord im Mittelalter, Göttingen, Vandenhoeck Ruprecht, 2003.

García y García, Antonio (dir.), Synodicon Hispanum, Madrid, BAC, 1997 y ss., vol. VII (Burgos y Palencia).

García Oro, José, Galicia en la baja Edad Media: Iglesia, señorío y nobleza, La Coruña, Toxosoutos, 1999.

Gauvard, Claude, Violencia, en Le Goff, Jacques; Schmitt, Jean Claude (eds.), Diccionario razonado del Occidente medieval, Madrid, Akal, 2003, pp. 811-816.

Gauvard, Claude, Violence et ordre public au Moyen Âge, París, Picard, 2005. 
Guerrero Navarrete, Yolanda, Orden público y corregidor en Burgos (siglo $X V$ ), "Anales de la Universidad de Alicante. Historia Medieval" 13 (2000-2002), pp. 6-113.

Guerrero Navarrete, Yolanda, Rey, nobleza y élites urbanas en Burgos (siglo $X V$ ), en Foronda, François; Carrasco Manchado, Ana Isabel (coords.), El contrato político en la corona de Castilla. Cultura y sociedad políticas entre los siglos X al XVI, Madrid, Dykinson, 2008, pp. 241-279.

Guijarro González, Susana, Antigüedad, costumbre y exenciones frente a innovación en una institución medieval: el conflicto entre el maestrescuela y el cabildo de la catedral de Burgos (1456-1472), "Hispania Sacra" 60/121 (2008), pp. 67-94.

Guijarro González, Susana, Jerarquía y redes sociales en la Castilla medieval. La provisión de beneficios eclesiásticos en el cabildo de la catedral de Burgos, "Anuario de Estudios Medievales" 38/1 (2008), pp. 271-299.

Jaritz, Gerhard; Marinkovic, Ana (eds.), Violence and the medieval clergy, Krems, Central European University, 2011.

Kaeuper, Richard William (ed.), Violence in medieval society, Rochester, Boydell Press, 2000.

López, Gregorio (ed.), Las Siete Partidas, Madrid, Boletín Oficial del Estado, 1985, 3 vols (facsímil de la ed. de Salamanca, Andrea de Portonaris, $1555)$.

López Martínez, Nicolás, Don Luis de Acuña, el cabildo de Burgos y la reforma (1456-1495), "Burgense" 2 (1961), pp. 185-317.

Mansilla Reoyo, Demetrio, Catálogo documental del Archivo Catedral de Burgos (804-1416), Burgos, CSIC, 1971.

Marques, Maria Alegria Fernandes, Casos de violência em ambiente eclesiástico: contributo do Bulário Português (sécs. XII-XIII), "Revista Portuguesa de História” 37 (2005), pp. 343-360.

Martín Benito, José Ignacio; González Rodríguez, Rafael, Lucha de bandos y beneficios eclesiásticos en los encastillamientos de Ciudad Rodrigo (14751520), "Studia Historica. Historia Medieval” 17 (1999), pp. 263-293.

Martínez Díez, Gonzalo, La Iglesia de Burgos, en Bartolomé Martínez, Bonifacio (coord.), Historia de las diócesis españolas, Madrid, BAC, 2004, vol. XX, pp. 7-121.

Marzoa Rodríguez, Ángel, La censura de excomunión. Estudio de su naturaleza jurídica en los siglos XIII al XV, Pamplona, Universidad de Navarra, 1985.

Mendoza Garrido, Juan Miguel, Delincuencia y represión en la Castilla bajomedieval: los territorios castellano-manchegos, Granada, Grupo Editorial Universitario, 1999. 
Narbona Vizcaíno, Rafael, Malhechores, violencia y justicia ciudadana en la Valencia bajomedieval (1360-1399), Valencia, Ayuntamiento, 1990.

Nieto Soria, José Manuel, Iglesia y génesis del Estado Moderno en Castilla (1369-1480), Madrid, Universidad Complutense, 1993.

Nieto Soria, José Manuel, Un crimen en la corte. Caída y ascenso de Gutierre Álvarez de Toledo, Señor de Alba (1376-1446), Madrid, Sílex, 2006.

Polanco Pérez, Arturo, Violencia verbal en el estamento eclesiástico palentino a través de las Actas Capitulares durante el siglo XV, "Publicaciones de la Institución Tello Téllez de Meneses” 72 (2001), pp. 373-380.

Pulgar, Fernando del, Crónica de los Reyes Católicos, ed. de Juan de Mata Carriazo, Granada, Universidad, 2008, 2 vols. (facsímil de la edición de Madrid, Espasa-Calpe, 1943).

Rilova Pérez, Isaac, Burgos en la primera mitad del siglo XV. La ciudad, la Iglesia y la familia conversa de los Cartagena, Burgos, Dossoles, 2008.

Ruiz de la Peña, Juan Ignacio, Las ciudades de señorío eclesiástico y los conflictos por el control del gobierno local (1252-1350), en Iglesia Duarte, Juan Ignacio de la (coord.), Conflictos políticos, sociales $e$ intelectuales en la España de los siglos XIV y XV. XIV Semana de Estudios Medievales de Nájera, Logroño, Instituto de Estudios Riojanos, 2004, pp. 113-145.

Sabaté Curull, Flocel, La pena de muerte en la Cataluña bajomedieval, "Clío \& Crimen" 4 (2007), pp. 117-276.

Sainz, Marta (coord.), Seminario sobre el Castillo de Burgos (1994), Burgos, Aldecoa, 1997.

Serrano, Luciano, Los Reyes Católicos y la ciudad de Burgos desde 1451 a 1492, Madrid, CSIC, 1943.

Solórzano Telechea, Jesús Ángel, Concubinarios, herejes y usurpadores: justicia eclesiástica, comunicación y propaganda en Las Montañas del obispado de Burgos en el siglo XV, "En la España Medieval" 33 (2010), pp. 233-257.

Soria-Audebert, Myriam, La crosse brisée: des evêques agresées dans une Eglise en conflits (royaume de France, fin Xe-début XIIIe siècle), Turnhout, Brepols, 2005.

Vicario Santamaría, Matías (dir.), Catálogo del Archivo Histórico de la catedral de Burgos, Burgos, Caja Círculo, 1998 y ss.

Fecha de recepción del artículo: mayo 2012

Fecha de aceptación y versión final: febrero 2013 